\title{
Importance of using roller compacted concrete in techno- economic investigation and design of small dams
}

\author{
Bouchrit Rouissat $^{1}$ (D) N. Smail ${ }^{1} \cdot$ S. Zenagui ${ }^{1}$
}

Received: 28 February 2017/ Accepted: 18 July 2017/Published online: 25 July 2017

(C) The Author(s) 2017. This article is an open access publication

\begin{abstract}
In recent years, and under constraints caused by persistent drought, Algeria has launched a new mobilization strategy for surface water resources from small and medium dams. However, by making a review of the studies and achievements of twenty small dams in the west of Algeria, some deficiencies appeared. In addition to reservoir siltation assessment, operation spillways have been the major constraint on the reliability of these types of dams. The objective of this paper is to use the roller compacted concrete (RCC) for small dams' design for the benefit it offers and its ability to incorporate spillways. The development of this reflection was applied to the Khneg Azir earth dam situated in southwest of Algeria. Its uncontrolled lateral spillway has registered significant damage following the flood of October 2005, amounted, at that time, to more than 100 million Algerian dinars (1 million US Dollars). The present research encompasses a technical and economical comparative analysis concerning multiple criteria dam design types coupled with the conjugation of the spillways. Thus, on the basis of financial estimates calculated for all design types, the variant RCC remains competitive with that of the earth dam's spillway isolated (Less than $40 \%$ of the cost). To assess the mechanical behavior of the foundations for both types of dams, (earth and RCC dams), numerical modeling has been undertaken, according to the comparative analysis of deformations in the foundations. Analysis of deformations showed that the average foundation deformations was between $(0.052-0.85) \mathrm{m}$ for earth dam and (0.023-0.373) $\mathrm{m}$ for RCC dam. These
\end{abstract}

Bouchrit Rouissat

b_rouissat@yahoo.fr

1 RISAM Laboratory, Faculty of Technology, University of Tlemcen, Post Office Box 119, 13000 Tlemcen, Algeria economical and technical considerations open up important prospects for the use of RCC in the design of small dams.

Keywords Earth dam · RCC dam · Frontal spillway · Lateral spillway $\cdot$ Deformations

\section{Introduction}

When the site conditions are favorable, the RCC dam finds its justification in multiple benefits: spillways easily combined with the dam, intensive mechanization of work reducing delivery times and its economic competitiveness (Zdiri et al. 2006). However, the great advantage of this type of dam is the integration of the spillways at the dam. This advantage gives a great opportunity at the relatively high flood sites. Thus, it can become competitive at the expense of other disadvantages: volume of the concrete, demands on the foundation deformation moduli, thermal stress, etc. (Goubet 1992).

One of the best solutions for dams' design is RCC (Roller Compacting concrete) due to its economic benefits and construction time. In comparison with conventional concrete dam, RCC dam can decrease the costs in ranging from 25 to 50 percent. Constructing the spillway in dam's body is cost-effective comparing with the embankment dams that require using spillways in an abutment (Zarrin et al. 2016).

In Algeria, the means of conventional surface water resource mobilization has always been oriented towards large dams. Nevertheless, time's realizations of these structures (studies, realization, financing, etc.) have led to a gap between needs and demands. Under the pressures and tensions caused by persistent drought, the government has committed significant investments for the mobilization of 
surface water resources from small dams. These structures, of a height between 10 and $25 \mathrm{~m}$, are, exclusively, intended for the purpose of irrigation of small perimeters areas. They are designed in clay, homogeneous or with central core. The spillways are isolated from the dams.

The assessment of project flows by empirical models (no gauging of small watersheds) was the main cause of degradation observed on the spillways (Rouissat and Smail 2009a). The expertises carried out on twenty small dams in western Algeria showed that, in most cases, the recorded degradations are due to the inadequacy of spillway's capacities (Rouissat and Smail 2009b).

The reflection undertaken in this paper concerns the analysis of using roller compacted concrete (RCC) in design of small dams.

Additionally, we propose a techno-economic analysis between the spillways designs of small earth dams, and those incorporated in RCC dam's body. The development of this reflection was applied to the case of Khneg Azir earth dam in southwest Algeria.

On the economical level, four variants were analyzed: earth dam with two types of spillways (lateral and frontal), fully submersible RCC dam and incorporated spillway on the dam. The design calculations carried out on the four variants have the objective of estimating the volumes of the works and consequently the costs of the various variants.

On the technical level, and particularly the aspect related to the deformation of the foundations, a numerical modeling has been developed for different deformation moduli to judge the adaptation of the RCC dam type according to the quality of the foundations.

\section{Characteristics of Khneg Azir dam}

The Khneg Azir small dam is located on Mellouk river, at the remote town of Kaf Lahmar about $50 \mathrm{~km}$ from the province of El Bayadh. The lambert site coordinates are $(X=329.30, Y=363.30)$.

The structure is a homogeneous clay dam with a height of $15 \mathrm{~m}$. The characteristics of the spillway are:

- Lateral uncontrolled spillway

- Flood frequency 1\%: $292 \mathrm{~m}^{3} / \mathrm{s}$

- Charge over the threshold: $2.5 \mathrm{~m}$

- Threshold: length $56 \mathrm{~m}$

- Trapezoidal channel: $150 \mathrm{~m}$ in length and $1.86 \%$ in slope

- Fast channel: $32.5 \mathrm{~m}$ in length and $21 \%$ in slope

- Basin of dissipation with drowned jump: $16.5 \mathrm{~m}$ in length and $5.5 \mathrm{~m}$ in deep (Hydro Projet Ouest 2000).

The flood recorded in October 2005 caused enormous damages to the spillway due to insufficient evacuation capacity (Rouissat 2006). Figures 1 and 2 show,

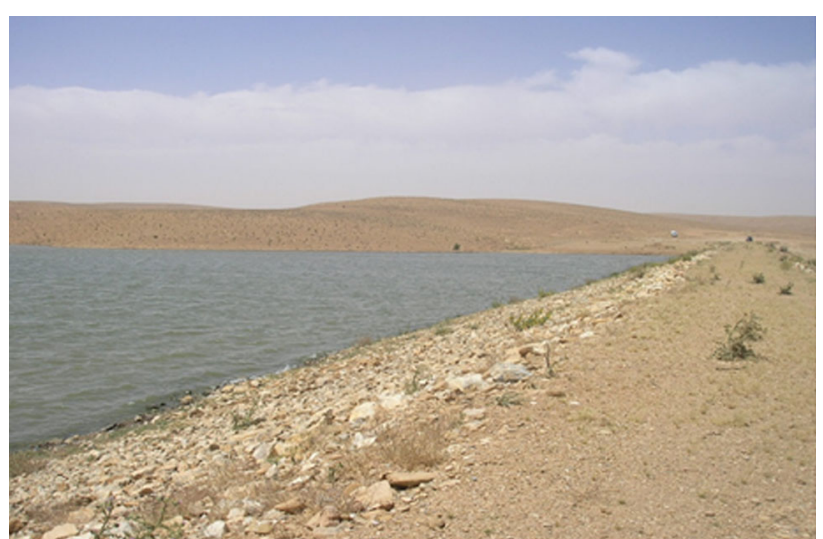

Fig. 1 View of the dam

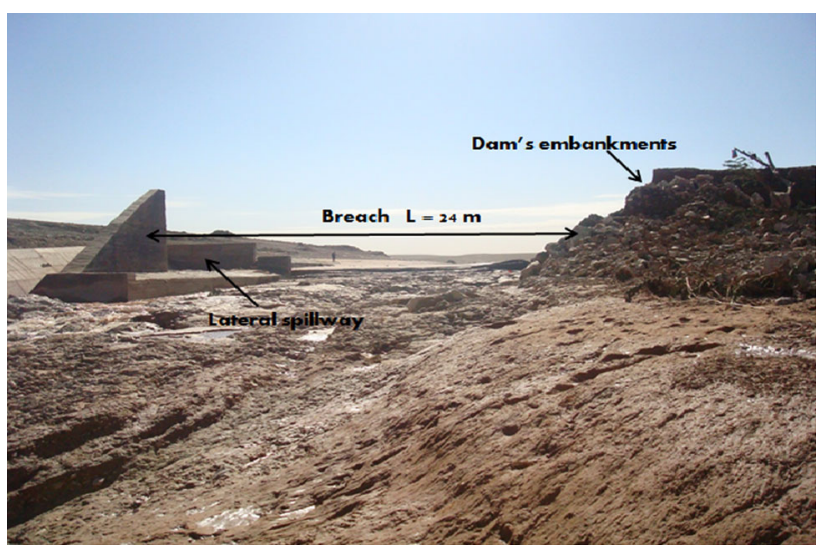

Fig. 2 Damages recorded in spillway's zone-October 2005

respectively, a view of the dam and the damages recorded in spillway zone.

\section{Methodology}

The technical and economic study included the following methodology:

- Calculations and design of the spillways (earth dam) for two design types: lateral and frontal spillway (often adopted solution for small earth dams),

- Projection, calculations and design of RCC dam's spillway,

- Analysis of the RCC dam's stability,

- Numerical modeling for both types of dams (earth and RCC dams) in order to launch a comparative study of behavior especially with regard to deformations with different types of foundations

- Technical and economical comparative analysis between multiple criteria of types dam design coupled with the conjugation of the spillways. 


\section{Results and discussions}

The objective of the hydraulic calculations is the determination of spillways geometries allowing estimating is financial costs.

\section{Hydraulic resizing: lateral spillway type}

For the lateral spillway type, the hydraulic calculations included the evaluation of the following parameters:

- Calculation of hydraulic parameters at the threshold (velocity, water level, and specific flow) by subdividing the threshold into 10 sections,

- Determination of the flow parameters at the channel and fast channel by plotting the discharge capacity curves on these sections, and projection of a stilling basin by evaluation of its depth, hydraulic jump, jet lengths, and the combined depths of the hydraulic jump.

Table 1 summarizes all the results of hydraulic calculations developed for the earth dam variant with uncontrolled lateral spillway.

\section{Hydraulic resizing: frontal spillway type}

For the frontal spillway type, the hydraulic calculations included the evaluation of the following parameters:

- Calculation of water level, velocity and Froude number at the downstream of the spillway by the USBR method.

- Calculation of the hydraulic parameters at the level of the transition, of the convergent and the channel by plotting the discharge capacity curves on these sections and projection of a stilling basin by evaluation of its depth, hydraulic jump, jet lengths and the combined depths of the hydraulic jump.

Table 2 summarizes all the results of hydraulic calculations developed for the earth dam variant with uncontrolled frontal spillway.

\section{Submersible RCC dam's variant}

To overcome the constraints related to the use of empirical models in the flood project evaluation for isolated spillways design of earth dams, a variant of a submersible RCC dam has been studied with a spillway incorporated in dam's body. This variant is combined with ski jump for the energy dissipation.

Two alternatives were studied in relation to the threshold length: the completely submersible dam, and the dam spilling over half its crest length.

- $\quad$ Flow coefficient $m=0.5$

- Length of the dam crest: $370 \mathrm{~m}$

Table 3 shows the results of hydraulic calculations for the two RCC dam's variants, included the evaluation of water level, velocity and Froude number at the downstream of the dam by the USBR method and calculation of ski jump length for a jump's curvature radius of $45^{\circ}$.

\section{RCC dam's stability criterions}

The stability against sliding and overturning of the RCC dam was tested for several types of foundations based on friction coefficients between the dam and its foundations.

The parameters considered for checking the structural stability of RCC dam are summarized as follows:

- Water load: $12.7 \mathrm{~m}$

- Dam's crest: $6 \mathrm{~m}$

- Slope of dam upstream facing: $1 \mathrm{H} / 1 \mathrm{~V}$

- Slope of dam downstream facing: $0.8 \mathrm{H} / 1 \mathrm{~V}$

- Trapezoidal diagram of under pressure at foundations

- Silting height: $6.35 \mathrm{~m}$ with a density of $17.7 \mathrm{KN} / \mathrm{m}^{3}$

- RCC density: $23.25 \mathrm{KN} / \mathrm{m}^{3}$

- Foundations cohesion: $C=60 \mathrm{KN} / \mathrm{m}^{2}$.

Considering $P$, the dam weight, $S$, the under pressure in foundations, $F$, the contact surface between the dam and its foundations, $F_{1}$ and $F_{2}$, respectively, the forces exerted by water and sediments at the upstream facing of the dam, the

Table 1 Results of hydraulic calculations-lateral spillway variant

\begin{tabular}{lllll}
\hline Section & 1 & 2 & 3 & 4 \\
& Threshold & Channel & Fast channel & Basin of dissipation \\
\hline Bottom slope $(\%)$ & 3.5 & 1.86 & 21 & - \\
Unit flow $q\left(\mathrm{~m}^{3} / \mathrm{s} . \mathrm{ml}\right)$ & 5.21 & 15 & 15 & 12.14 \\
Velocity $V(\mathrm{~m} / \mathrm{s})$ & 7 & 12 & 25 & 8.11 \\
Water level $(\mathrm{m})$ & Input: 1.33 & Input: 2.14 & Input: 1.25 & Input: 0.60 \\
& Output: 2.14 & Output: 1.25 & Output: 0.60 & Output: 1.50 \\
\hline
\end{tabular}


Table 2 Results of hydraulic calculations-frontal spillway variant

\begin{tabular}{|c|c|c|c|c|c|}
\hline Section & $\begin{array}{l}1 \\
\text { Threshold }\end{array}$ & $\begin{array}{l}2 \\
\text { Transition }\end{array}$ & $\begin{array}{l}3 \\
\text { Convergent }\end{array}$ & $\begin{array}{l}4 \\
\text { Channel }\end{array}$ & $\begin{array}{l}5 \\
\text { Basin of dissipation }\end{array}$ \\
\hline Bottom slope (\%) & - & - & 1.86 & 21 & - \\
\hline Unit flow $q\left(\mathrm{~m}^{3} / \mathrm{s} . \mathrm{ml}\right)$ & 5.21 & 5.21 & 10 & 10 & 8.3 \\
\hline Velocity $V(\mathrm{~m} / \mathrm{s})$ & 3.32 & 3.32 & 13 & 43 & 5.6 \\
\hline Water level (m) & - & 1.57 & 0.74 & 0.23 & 1.5 \\
\hline
\end{tabular}

Table 3 Results of hydraulic calculations-RCC dam variant

\begin{tabular}{llll}
\hline Dumping zone & Downstream of the dam & & \\
\cline { 2 - 4 } $\mathrm{H}_{1}(\mathrm{~m})$ & $V(\mathrm{~m} / \mathrm{s})$ & $H_{2}(\mathrm{~m})$ & Length (m) of jet (ski jump) \\
\hline $\begin{array}{l}\text { RCC dam-length spill } L=370 \mathrm{~m} \\
\quad\end{array}$ & 3.6 & 0.22 & 1.4 \\
$\begin{array}{l}\text { RCC dam-length spill } L=185 \mathrm{~m} \\
\quad\end{array}$ & 4.8 & 0.33 & 2.4 \\
\hline
\end{tabular}

Table 4 Results of dam's stability analysis-RCC variant

\begin{tabular}{|c|c|c|c|c|c|c|}
\hline Foundations types & Hydrostatic strength $(\mathrm{KN})$ & Sediment strength (KN) & Dam's weight $(\mathrm{KN})$ & Under pressure $(\mathrm{KN})$ & $K_{\text {sliding }}$ & $K_{\text {overturning }}$ \\
\hline$f=0.22$ & 791.1 & 316.5 & 2526.1 & 121.1 & 1.26 & 4.3 \\
\hline$f=0.33$ & & & & & 1.5 & \\
\hline$f=0.67$ & & & & & 2.24 & \\
\hline
\end{tabular}

safety coefficients against sliding $\left(K_{\text {sliding }}\right)$ and overturning ( $\left.K_{\text {overturning }}\right)$ are given below:

$K_{\text {sliding }}=\frac{f \cdot \sum F_{V}+C \cdot F}{\sum F_{H}}=\frac{f \cdot(P-S)+C \cdot F}{F_{1}+F_{2}}$

$K_{\text {overturning }}=\frac{\sum M_{H}}{\sum M_{V}}=\frac{M(P, S)}{M\left(F_{1}, F_{2}\right)}$.

Table 4 summarizes the results of the dam stability analysis against sliding and overturning for different types of foundations.

\section{Comparative financial analysis}

Hydraulic calculations were used to determine the geometry of the various elements of the spillways. In fact, for the lateral and frontal spillways of the earth dam, the slopes were used to estimate the volumes of earthworks, and the specific flow rates allow evaluating the width's elements. The heights of the walls were determined by evaluating the water levels in threshold, channel and fast channel.

The stilling basin works have been evaluated by the determination of its depth, the hydraulic jump, jet lengths and the combined depths of the hydraulic jump. For the RCC dam, the volume of the concrete was evaluated by considering the profile of the dam, the cross section of the valley, the water levels, and the length of jet (ski jump). Table 5 summarizes a synthesis on the spillways dimensions determined by hydraulic calculations.

To draw up an economic comparison, Table 6 summarizes a synthesis of volumes of works for the analyzed variants.

Figure 3 summarizes, after financial estimation of the volume of work, the economic comparison between designs variants.

\section{Analysis of dams' deformations}

The homogeneous earth dams have the great advantage in case of quantitative and qualitative availability of waterproof materials, and for their economic competitiveness. The constraints related to this type of dams lies in their sensitivity to design floods with great prejudice for the safety of the spillway and of the dam against flood. This security is particularly compromised if the evaluation of project flood is empirical. 
Table 5 Geometry parameters of spillways

\begin{tabular}{lllll}
\hline Spillway's types & Geometry parameters & & & \\
\hline Lateral & Threshold & Channel & Fast channel & Basin of dissipation \\
& Length: $56 \mathrm{~m}$ & Length: $150 \mathrm{~m}$ & Length: $32 \mathrm{~m}$ & Hydraulic jump length: $16.5 \mathrm{~m}$ \\
& Initial width: $1 \mathrm{~m}$ & Width: $19.5 \mathrm{~m}$ & Width: $19.5 \mathrm{~m}$ & Jet length: $32.3 \mathrm{~m}$ \\
& Final width: $19.5 \mathrm{~m}$ & & & Basin of dissipation \\
Frontal & Transition & Convergent & Channel & Hydraulic jump length: $16.3 \mathrm{~m}$ \\
& Length: $56 \mathrm{~m}$ & Length: $67 \mathrm{~m}$ & Length: $59.5 \mathrm{~m}$ & Jet length: $34.3 \mathrm{~m}$ \\
\hline
\end{tabular}

Table 6 Quantity of construction works

\begin{tabular}{llll}
\hline Variant & Earthworks & Embankments & Concrete \\
\hline $\begin{array}{l}\text { Earth dam } \\
\text { Lateral spillway }\end{array}$ & $V=31,676 \mathrm{~m}^{3}$ & $V=88,000 \mathrm{~m}^{3}$ & $V=4265 \mathrm{~m}^{3}$ \\
$\begin{array}{l}\text { Earth dam } \\
\text { Frontal spillway }\end{array}$ & $V=40,853 \mathrm{~m}^{3}$ & $V=6151 \mathrm{~m}^{3}$ & \\
RCC dam & $V=2218 \mathrm{~m}^{3}$ & $($ RCC) \\
$\begin{array}{l}\text { Length spill } \\
L=370 \mathrm{~m}\end{array}$ & & $V=16,615 \mathrm{~m}^{3}$ \\
RCC dam & $V=2313 \mathrm{~m}^{3}$ & $($ RCC) \\
Length spill & & $V=13170 \mathrm{~m}^{3}$ \\
$L=185 \mathrm{~m}$ & &
\end{tabular}

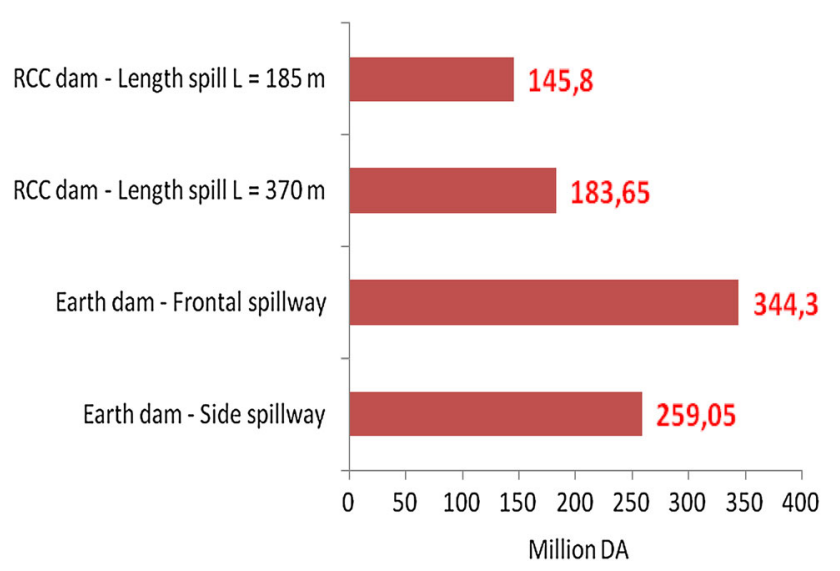

Fig. 3 Financial comparison between design variants

The use of RCC for gravity profiles has many advantages; in particular the incorporation of the spillway in dam's body. However, for construction, gravity dams need good foundations and topography to perform better throughout in their lifetime (Rampure and Mangulkar 2016).

The concrete dams require the foundation and abutments to have sufficient bearing capacity, and deformation rigidity. Thus, the determination of foundation geology is one of the key issues for these dams (Renkun 2016).
To analyze the influence of this last parameter on the technical and economical choice of the dam's variant, a numerical modeling hinging has been undertaken using the ANSYS computer code to analyze the mechanical behavior of earth and RCC dam's variants.

The ANSYS calculation code used for modeling is based on the finite element method. The criterion of plasticity used usually in ANSYS code is Von Mises stress criterion for ductile materials.

For the analysis of the dams' deformations, ANSYS code proposes the Drucker-Prager stress criterion which constitutes a generalization of Von Mises criterion taking into account the first invariant of the stress tensor and the second invariant of the deviatoric stress tensor.

Additionally, to analyze the influence of the foundations types, in particular on the deformations, it was performed an analysis set according to the deformation modulus $\mathrm{E}$ of the foundations. For example, Figs. 4, 5, 6 and 7 show the deformations and constraints for the earth and RCC dam (deformation modulus of foundations $E=30 \mathrm{MPa}$ ).

The characteristics of the materials used for modeling are summarized in Table 7 . The boundary conditions used are the blockage of horizontal and vertical displacements at the foundation base and of horizontal displacements at the lateral faces of foundations. Regarding the type of load, it 
Fig. 4 Deformations (m)Earth dam with

$E_{\text {Fundations }}=30 \mathrm{MPa}$
Max displacement

1.047

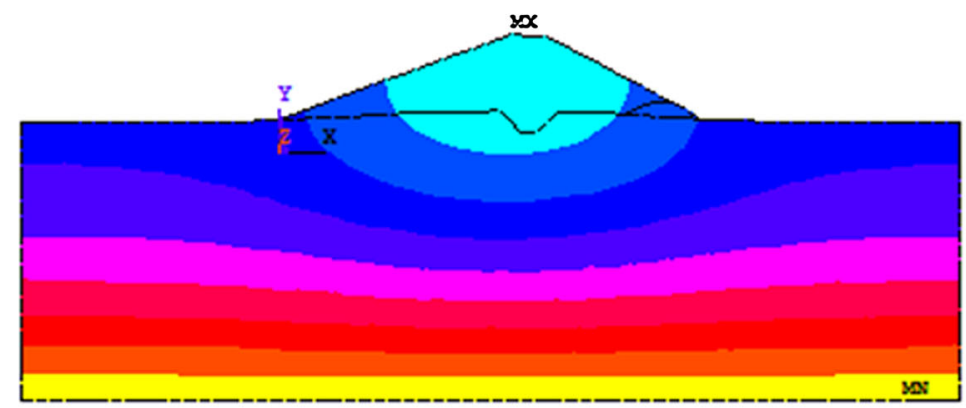

Fig. 5 Constraints $\left(\mathrm{N} / \mathrm{m}^{2}\right)$ Earth dam with

$E_{\text {Fundations }}=30 \mathrm{MPa}$

Max displacement

1.047

Max constraint

$.106 \mathrm{E}+07$

Min constraint

8864

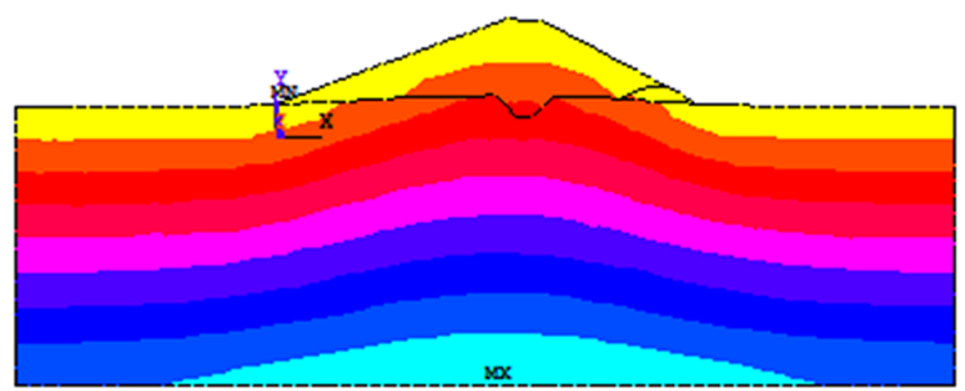

\begin{tabular}{|llllllllll}
\hline 8864 & 126012 & 243159 & 360306 & 477453 & 594602 & 711748 & 828895 & 966043 & $.2065+07$ \\
\hline
\end{tabular}

was considered the own weight of the dam (empty reservoir) and the own weight with water pressure (full reservoir).

As a synthesis of the main results obtained in this paper, Fig. 8 summarizes deformations analysis for all modeled variants.

\section{Conclusion}

All hydraulic calculations engaged on the different variants were used to define the geometry elements of spillways.

Checking the structural stability of RCC gravity profile against sliding and overturning, led to the stability criteria 
Fig. 6 Deformations (m)RCC dam with

$E_{\text {Fundations }}=30 \mathrm{MPa}$

Fig. 7 Constraints $\left(\mathrm{N} / \mathrm{m}^{2}\right)$ RCC dam with

$E_{\text {Fundations }}=30 \mathrm{MPa}$
Max displacement

0.390945

NNSYS
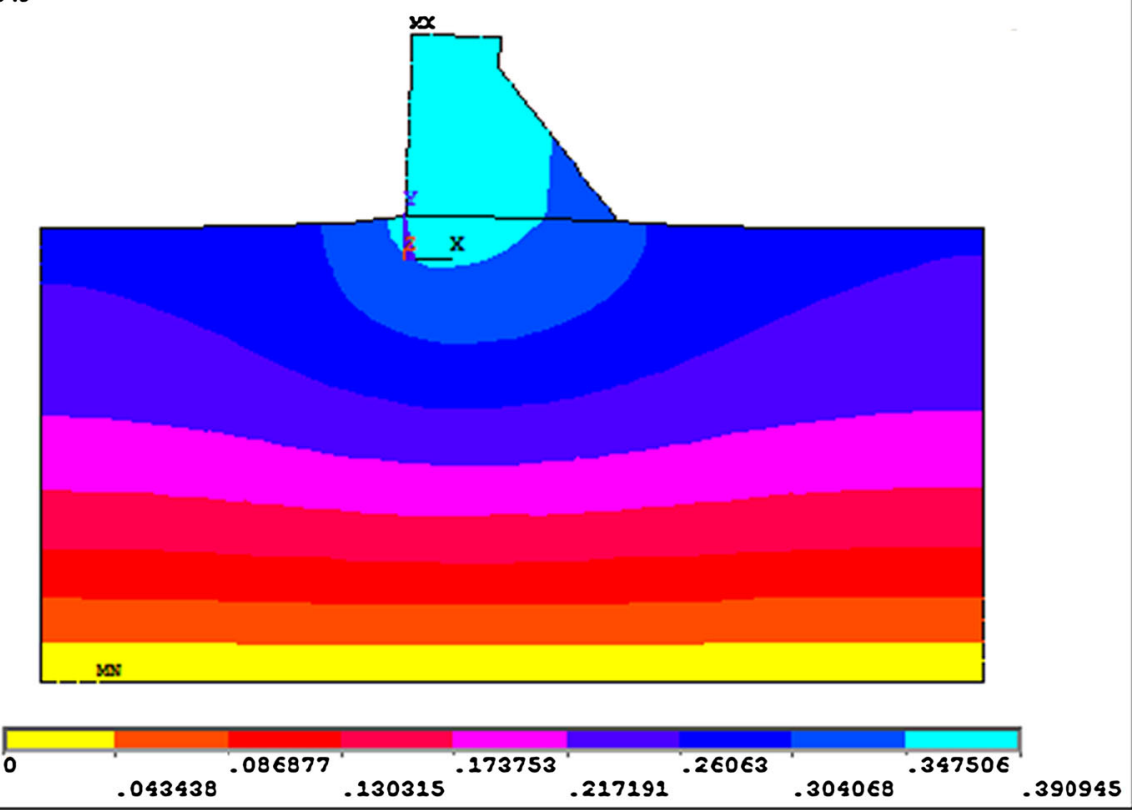

Max displacement

0.390945

Max constraint

872249

Min constraint

5093
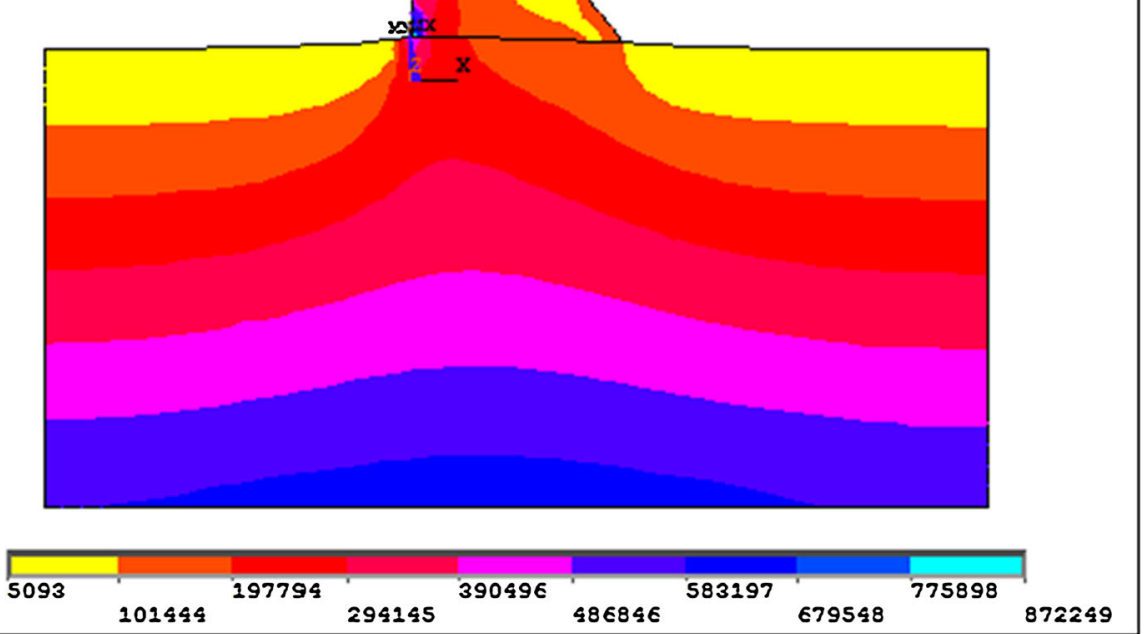

Table 7 Characteristics of dam's materials

\begin{tabular}{lll}
\hline Parameters & Earth dam & RCC dam \\
\hline Deformation modulus $(\mathrm{MPa})$ & 28 & 250 \\
Poison coefficient & 0.3 & 0.20 \\
Density $\left(\mathrm{kg} / \mathrm{m}^{3}\right)$ & 1800 & 2000 \\
\hline
\end{tabular}

ensured according to the profile designed for different types of support foundations.

The calculations and developed hydraulic checks were used to evaluate of volumes of work completed by their financial estimate, and to establish an economic comparison of different variants analyzed. 
Fig. 8 Summary of foundations deformations for different design variants

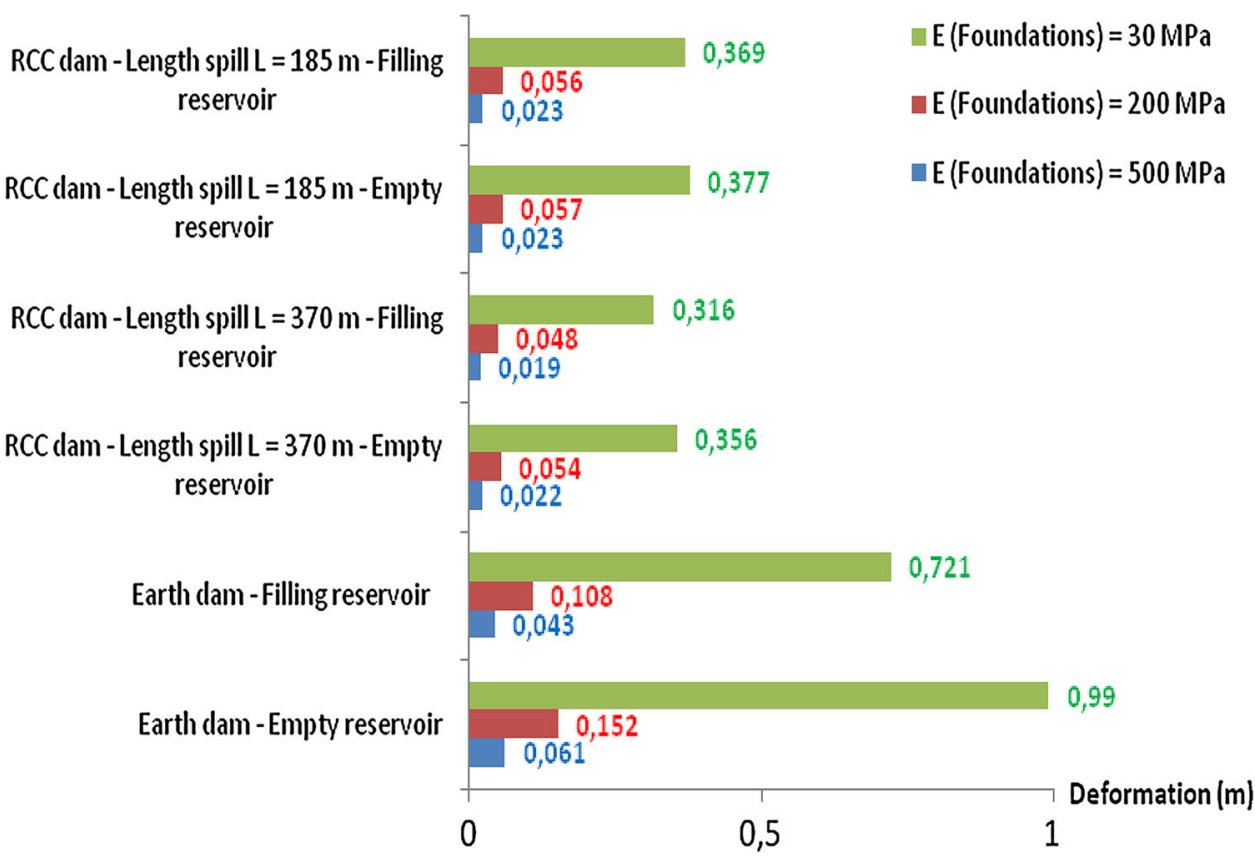

Thus, on the basis of financial estimates developed for all variants, the RCC dam remains competitive with that of the earth dam with isolated spillway.

Numerical modeling has led, according to the deformation analysis in the foundation, to a comparison of the proposed variants. Deformations calculated by modeling resulted in average values between $(0.052-0.85) \mathrm{m}$ and (0.023-0.373) $\mathrm{m}$, respectively, for the earth and RCC dams' variants.

Finally, according to the results obtained, the use of RCC for the design of small dams in Algeria is an interesting solution, which will solve the constraints to the design of this type of structures with isolated spillways.

Open Access This article is distributed under the terms of the Creative Commons Attribution 4.0 International License (http:// creativecommons.org/licenses/by/4.0/), which permits unrestricted use, distribution, and reproduction in any medium, provided you give appropriate credit to the original author(s) and the source, provide a link to the Creative Commons license, and indicate if changes were made.

\section{References}

Goubet A (1992) Evacuateurs de crues en marches d'escalier. La houille blanche 2(3):159

Hydro Projet Ouest (2000) Etude d'Avant Projet détaillé du barrage Khneg Azir calculs hydrauliques

Rampure AB, Mangulkar M (2016) Finite element analysis of concrete gravity dam by using STAAD-PRO. Int J Eng Res 5(3):550

Renkun W (2016) Key technologies in the design and construction of $300 \mathrm{~m}$, ultra-high arch dams. J Eng 2(3):350-351

Rouissat B (2006) Expertise du barrage Khneg Azir. Final report

Rouissat B, Smail N (2009a) Conception des petits barrages: leçons et apport de l'approche systémique. First Mediterranean Symposium Geoengineering, Algiers, Algeria

Rouissat B, Smail N (2009b) Influence des erreurs de conception sur le fonctionnement des évacuateurs des crues. Dimensionnement et fonctionnement des évacuateurs de crues, Paris, Colloque CFBR-SHF

Zarrin O, Shirazi MR, Moniri H, Moniri M (2016) Roller-compacted concrete dams rehabilitation in terms of different problem. J Civil Environ Eng 6(2):1-4

Zdiri M, Ben Ouezdou M, Neji J (2006) Les bétons compactés au rouleau à faible dosage en ciment, une solution pour les routes rurales: cas des matériaux de gisements locaux. Revue HTE $134: 34-44$ 